Provided for non-commercial research and education use. Not for reproduction, distribution or commercial use.

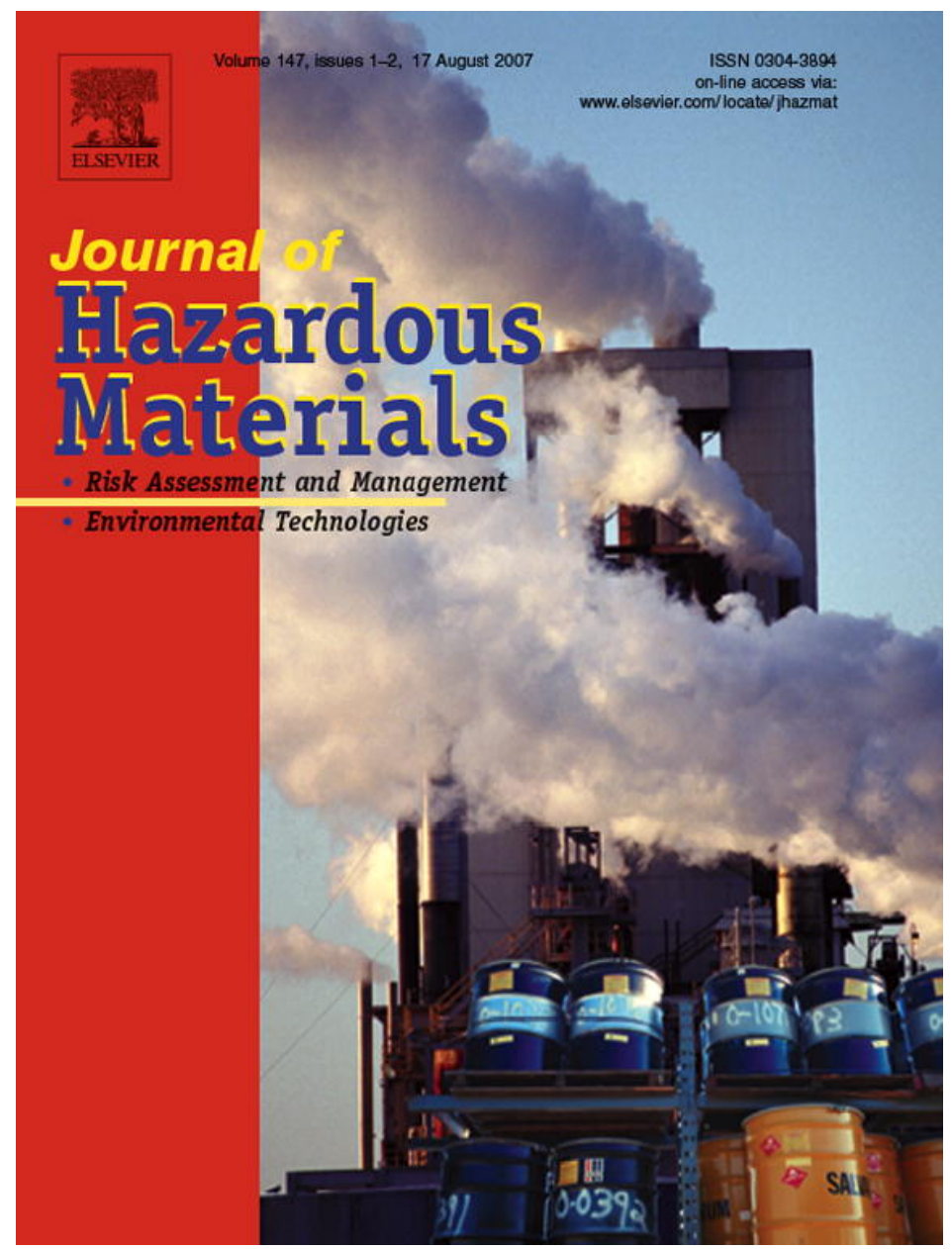

This article was published in an Elsevier journal. The attached copy

is furnished to the author for non-commercial research and education use, including for instruction at the author's institution, sharing with colleagues and providing to institution administration.

Other uses, including reproduction and distribution, or selling or licensing copies, or posting to personal, institutional or third party websites are prohibited.

In most cases authors are permitted to post their version of the article (e.g. in Word or Tex form) to their personal website or institutional repository. Authors requiring further information regarding Elsevier's archiving and manuscript policies are encouraged to visit: 


\title{
Removal of residual phenols from coke wastewater by adsorption
}

\author{
I. Vázquez, J. Rodríguez-Iglesias, E. Marañón*, L. Castrillón, M. Álvarez \\ Department of Chemical and Environmental Engineering, Higher Polytechnic School of Engineering, University of Oviedo, \\ Campus de Viesques, Edificio de Energía, 33204 Gijón, Spain
}

Received 19 May 2006; received in revised form 4 January 2007; accepted 8 January 2007

Available online 12 January 2007

\begin{abstract}
After biological treatment, coke wastewater contains small amounts of phenolic compounds resistant to such treatment. The removal of phenols and COD from coke wastewater subjected to biological treatment was studied. The adsorbents used were granular activated carbon and the resins XAD-2, AP-246 and OC-1074. Equilibrium, kinetics and column assays were carried out, fitting the equilibrium data to Langmuir and Freundlich models and the kinetic data to the Lagergren equation. The best results were obtained with GAC, which presented higher adsorption capacities. In the equilibrium assays, the adsorption capacities $(Q)$ found were $1.48 \mathrm{mg} \mathrm{g}^{-1}$ for GAC versus 0.07 and $0.04 \mathrm{mg} \mathrm{g}^{-1}$ for resins AP-246 and OC-1074, respectively. In the kinetic assays, the values of the Lagergren adsorption parameter, $q_{\mathrm{e}}$, were $1.69,0.15$ and $0.14 \mathrm{mg} \mathrm{g}^{-1}$ for $\mathrm{GAC}$, $\mathrm{AP}_{-2}-246$ and OC-1074, respectively. In the column assays, the dynamic capacity of GAC for up to 480 bed volumes was $1.82 \mathrm{mg} \mathrm{mL}^{-1}$. No saturation was obtained for this volume due to the asymptotic shape of the breakthrough curve, whereas for the same percolated volume, the resins AP-246 and OC-1074 were saturated. These two resins presented similar saturation capacities of around $1.1 \mathrm{mg} \mathrm{mL}^{-1}$.
\end{abstract}

(C) 2007 Elsevier B.V. All rights reserved.

Keywords: Adsorption; Phenol; COD; Coke wastewater; Tertiary treatment

\section{Introduction}

Coke and coke by-products are produced via the pyrolysis of suitable grades of coal. The process also includes the processing of coke oven gas to remove tar, ammonia (recovered as ammonium sulphate), phenol, naphthalene, light oil, and sulphur before being used as fuel for heating the coke ovens. Coke wastewater originates from the ammonia scrubbing process.

Coke wastewater is a complex industrial wastewater present in most steelworks that contains considerable amounts of toxic compounds such as $\mathrm{CN}^{-}, \mathrm{SCN}^{-}$and phenols, as well as high concentrations of ammonium nitrogen and chlorides, though low concentrations of heavy metals and phosphorus [1,2]. It also contains small amounts of polyaromatic hydrocarbons and heterocyclic nitrogenous compounds [3-5]. Table 1 shows some typical values of the main pollutants in coke wastewater [6].

Abbreviations: COD, chemical oxygen demand; BV, bed volume; GAC, granular activated carbon; $\mathrm{CN}^{-}$, soluble cyanide; $\mathrm{SCN}$, thiocyanate; $\mathrm{NO}_{2}{ }^{-}$, nitrite; $\mathrm{NO}_{3}{ }^{-}$, nitrate; $\mathrm{Cl}^{-}$, chloride

* Corresponding author. Tel.: +34 98182027; fax: +34 985182010.

E-mail address: emara@uniovi.es (E. Marañón).
Individual concentrations of each component vary according to the type of coal used and modifications of each specific process [7].

Traditionally, expensive processes have been employed for coke wastewater treatment, such as the addition of caustic soda and steam stripping. More recently, biological treatments have been applied to reduce the pollutant load. Several treatment plants have already been built in the German district of Rhine Westphalia. Some processes, such as NITE/DENITE, ENSR Corp., Houston, TX patented, are based on biological treatment of coke wastewater without any prior pre-treatment, since no ammonium stripping is carried out. The best known biological treatment plants in Europe are Zentralkokerei Saar and Kaiserstuhl in Germany, Serèmage in France and Sidmar in Belgium. In Spain, the first biological plant was built at the end of 2003 at the Arcelor group facilities in Avilés (Asturias). This plant consists in a modification of a conventional activated sludge process using pure oxygen instead of air with an anoxic area for denitrification.

After this treatment, the concentration of phenols in the wastewater exceeded the limits established in both state regulations regarding direct discharge into watercourses (Royal Decree 606/2003) as well as regional regulations (Law 5/2002) 


\begin{tabular}{|c|c|}
\hline \multicolumn{2}{|c|}{ Nomenclature } \\
\hline$C$ & substrate concentration \\
\hline$C_{\mathrm{e}}$ & $\begin{array}{l}\text { the equilibrium concentration of the species in the } \\
\text { solution }\left(\mathrm{mg} \mathrm{L}^{-1}\right)\end{array}$ \\
\hline$C_{0}$ & substrate initial concentration \\
\hline$k$ & $\begin{array}{l}\text { constant of the Langmuir equation related to the } \\
\text { enthalpy of the process }\left(\mathrm{mg} \mathrm{L}^{-1}\right)^{-1}\end{array}$ \\
\hline$k^{\prime}$ & the equilibrium rate constant $\left(\min ^{-1}\right)$ \\
\hline$K_{\mathrm{F}}$ & $\begin{array}{l}\text { Freundlich surface adsorption equilibrium con- } \\
\text { stant }\left(\mathrm{mg} \mathrm{L}^{-1}\right)^{-1}\end{array}$ \\
\hline$n$ & heterogeneity factor \\
\hline$q_{\mathrm{e}}$ & $\begin{array}{l}\text { amount sorbed per specified amount of sorbent } \\
\left(\mathrm{mg} \mathrm{g}^{-1}\right)\end{array}$ \\
\hline$q_{\mathrm{t}}$ & amount of substrate sorbed at time $t\left(\mathrm{mg} \mathrm{g}^{-1}\right)$ \\
\hline$Q$ & $\begin{array}{l}\text { adsorption capacity to form the single layer } \\
\left(\mathrm{mg} \mathrm{g}^{-1}\right)\end{array}$ \\
\hline
\end{tabular}

Table 1

Typical pollutant concentrations in coke wastewater

\begin{tabular}{lccr}
\hline Parameter & \multicolumn{2}{c}{ Coke wastewater } & \\
\cline { 2 - 4 } & Australia & Germany & Spain \\
\hline BOD $_{5}\left(\mathrm{mg} \mathrm{L}^{-1}\right)$ & 610 & $1600-2600$ & 1150 \\
$\mathrm{COD}\left(\mathrm{mg} \mathrm{L}^{-1}\right)$ & 2200 & $4000-6500$ & 3030 \\
$\mathrm{TSS}\left(\mathrm{mg} \mathrm{L}^{-1}\right)$ & 50 & $2-10$ & 31 \\
$\mathrm{TKN}\left(\mathrm{mg} \mathrm{L}^{-1}\right)$ & 330 & $300-500$ & 1245 \\
$\mathrm{NH}_{4}^{+}-\mathrm{N}\left(\mathrm{mg} \mathrm{L}^{-1}\right)$ & 272 & $50-150$ & 1010 \\
$\mathrm{P}\left(\mathrm{mg} \mathrm{L}^{-1}\right)$ & $<1$ & $<1$ & $<1$ \\
${\mathrm{Phenol}\left(\mathrm{mg} \mathrm{L}^{-1}\right)}_{\mathrm{SCN}^{-}\left(\mathrm{mg} \mathrm{L}^{-1}\right)}^{333}$ & 184 & $400-1.200$ & 485 \\
$\mathrm{CN}^{-}\left(\mathrm{mg} \mathrm{L}^{-1}\right)$ & 93 & $200-500$ & 215 \\
\hline
\end{tabular}

regarding discharge into public sewage systems, which means that a polishing treatment is required.

Phenols can be highly toxic even at low concentrations and their concentrations in aquatic media are strictly limited by regulations. In recent years, several physico-chemical treatments have been proposed for obtaining efficient phenol removal, such as adsorption, air stripping, steam stripping, wet oxidation, heterogeneous photocatalysis and biological treatments [8-14].

In this paper, the possibility of using adsorbents for the removal of residual concentrations of phenols and COD in coke wastewater after biological treatment is studied.

\section{Materials and methods}

\subsection{Coke wastewater characteristics}

The coke wastewater used in this study came from the Arcelor plant in Aviles (Spain), which produces $1512 \mathrm{~m}^{3} \mathrm{~d}^{-1}$ of wastewater $\left(0.38 \mathrm{~m}^{3} \mathrm{t}^{-1}\right.$ coke). Its physico-chemical characteristics are shown in Table 2. The main pollutants present are ammonium nitrogen $\left(650-700 \mathrm{mg} \mathrm{L}^{-1}\right)$, phenols $\left(180-250 \mathrm{mg} \mathrm{L}^{-1}\right)$, thiocyanates (200-300 $\mathrm{mg} \mathrm{L}^{-1}$ ) and chemical oxygen demand
Table 2

Average pollutant concentration in coke wastewater before biological treatment

\begin{tabular}{|c|c|}
\hline Parameter & Average concentration \\
\hline $\mathrm{pH}$ & 8.1 \\
\hline Conductivity $\left(\mathrm{mS} \mathrm{cm}^{-1}\right)$ & 7.1 \\
\hline $\mathrm{COD}\left(\mathrm{mg} \mathrm{O}_{2} \mathrm{~L}^{-1}\right)$ & 1100 \\
\hline $\mathrm{BOD}_{5}\left(\mathrm{mg} \mathrm{O}_{2} \mathrm{~L}^{-1}\right)$ & 579 \\
\hline $\operatorname{TSS}\left(\mathrm{mg} \mathrm{L}^{-1}\right)$ & 32.0 \\
\hline $\operatorname{VSS}\left(\mathrm{mg} \mathrm{L}^{-1}\right)$ & 23.0 \\
\hline Phenols $\left(\mathrm{mg} \mathrm{L}^{-1}\right)$ & 207 \\
\hline Oil and grease $\left(\mathrm{mg} \mathrm{L}^{-1}\right)$ & 5.3 \\
\hline Alkalinity $\left(\mathrm{g} \mathrm{CaCO}_{3} \mathrm{~L}^{-1}\right)$ & 0.25 \\
\hline $\mathrm{NH}_{4}{ }^{+}-\mathrm{N}\left(\mathrm{mg} \mathrm{L}^{-1}\right)$ & 688 \\
\hline $\mathrm{TKN}\left(\mathrm{mg} \mathrm{L}^{-1}\right)$ & 757 \\
\hline $\mathrm{NO}_{3}-\left(\mathrm{mg} \mathrm{L}^{-1}\right)$ & 76.0 \\
\hline $\mathrm{SCN}^{-}\left(\mathrm{mg} \mathrm{L}^{-1}\right)$ & 267 \\
\hline $\mathrm{CN}^{-}\left(\mathrm{mgL}^{-1}\right)$ & 32 \\
\hline $\mathrm{PO}_{4}^{3-}\left(\mathrm{mg} \mathrm{L}^{-1}\right)$ & 0.5 \\
\hline $\mathrm{SO}_{4}^{2-}\left(\mathrm{mg} \mathrm{L}^{-1}\right)$ & 102 \\
\hline $\mathrm{S}^{2-}\left(\mathrm{mg} \mathrm{L}^{-1}\right)$ & 0.1 \\
\hline $\mathrm{Cl}^{-}\left(\mathrm{mg} \mathrm{L}^{-1}\right)$ & 1290 \\
\hline $\mathrm{Fe}\left(\mathrm{mg} \mathrm{L}^{-1}\right)$ & 4.4 \\
\hline $\operatorname{Mg}\left(\mathrm{mg} \mathrm{L}^{-1}\right)$ & 6.1 \\
\hline $\mathrm{Ca}\left(\mathrm{mg} \mathrm{L}^{-1}\right)$ & 11.0 \\
\hline
\end{tabular}

(1000-1200 $\mathrm{mg} \mathrm{L}^{-1}$ ), of which around $70 \%$ is made up of biodegradable matter. Another toxic pollutant present is cyanide $\left(20-45 \mathrm{mg} \mathrm{L}^{-1}\right)$. The wastewater was treated in a laboratoryscale activated sludge plant with the following characteristics (Fig. 1): an anoxic reactor for the denitrification process, an aerobic reactor for the biodegradation of phenols and thiocyanate followed by a settling tank to separate the biomass and a second aerobic reactor for the nitrification process, likewise followed by a settling tank.

The average composition of the effluent from this plant is shown in Table 3. The phenol concentration ranged from 8 to $2.5 \mathrm{mg} \mathrm{L}^{-1}$, COD from 500 to $400 \mathrm{mg} \mathrm{L}^{-1}, \mathrm{NH}_{4}{ }^{+}-\mathrm{N}$ from 30 to $40 \mathrm{mg} \mathrm{L}^{-1}$ and very low concentrations of $\mathrm{SCN}^{-}$and $\mathrm{CN}^{-}$. Adsorption experiments using several adsorbents were carried out in order to decrease the phenol content to values $\leq 2 \mathrm{mg} \mathrm{L}^{-1}$, thus enabling the wastewater to be discharged into the sewage system.

\subsection{Preliminary adsorption assays}

Initially, several assays were conducted to select the best adsorbents. The adsorbents used were: granular activated carbon

Table 3

Average pollutant concentration in coke wastewater after biological treatment

\begin{tabular}{lc}
\hline Parameter & Average concentration \\
\hline $\mathrm{pH}$ & 8.6 \\
$\mathrm{COD}\left(\mathrm{mg} \mathrm{L}^{-1}\right)$ & 430 \\
$\mathrm{SCN}^{-}\left(\mathrm{mg} \mathrm{L}^{-1}\right)$ & 1.2 \\
$\mathrm{NH}_{4}^{+}-\mathrm{N}\left(\mathrm{mg} \mathrm{L}^{-1}\right)$ & 34 \\
$\mathrm{TSS}\left(\mathrm{mg} \mathrm{L}^{-1}\right)$ & 60 \\
${\mathrm{Phenols}\left(\mathrm{mg} \mathrm{L}^{-1}\right)}_{\mathrm{CN}^{-}\left(\mathrm{mg} \mathrm{L}^{-1}\right)}^{5.3}$ \\
\hline
\end{tabular}




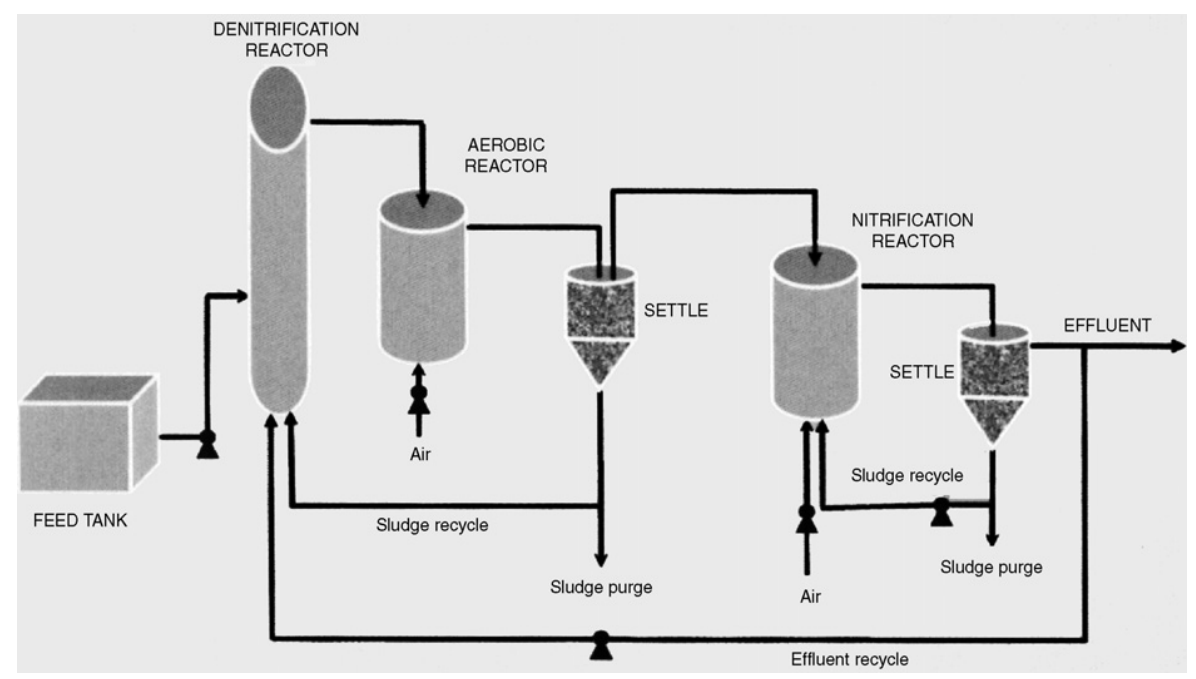

Fig. 1. Activated sludge laboratory-scale plant.

with different particle sizes (0.8, 1.0, 1.4 and $2.5 \mathrm{~mm}$ diameter), and the resins AP-246, XAD-2 and OC-1074, the characteristics of which are shown in Table 4.

\subsection{Equilibrium and kinetic assays}

The kinetic assays were carried out in $250 \mathrm{~mL}$ Erlenmeyer flasks sealed with Parafilm, to prevent the loss of phenol by volatilisation. In the flasks, $100 \mathrm{~mL}$ of phenol solution of known concentration $\left(5,10\right.$ and $\left.15 \mathrm{mg} \mathrm{L}^{-1}\right)$ and initial $\mathrm{pH} 8.4$ were put in contact with different amounts of adsorbents $(0.5,1$, 2 and $4 \mathrm{~g}$ ). The phenol solutions were prepared with original wastewater coming from the pilot-scale wastewater treatment plant at Arcelor facilities. The flasks were shaken using a VIBRATIC mixer for the selected time $(5,10,15,20,30,60$, $90,120,150$ and $180 \mathrm{~min})$. The assays were carried out at room temperature.

For the study of adsorption equilibrium at $20^{\circ} \mathrm{C}, 1,2$ and $4 \mathrm{~g}$ of adsorbents were put in contact with $100 \mathrm{~mL}$ of wastewater. The initial concentration of phenol ranged from 5 to $15 \mathrm{mg} \mathrm{L}^{-1}$ at a $\mathrm{pH}$ of 8.4. The flask were shaken using a VIBRATIC mixer for $24 \mathrm{~h}$. At the end of selected period time, the content of each flask was filtered trough a $0.45 \mu \mathrm{m}$ membrane filter and phenol concentration in the filtrate was determined.

\subsection{Column assays}

The column adsorption assays were conducted downflow in a glass column ( $2 \mathrm{~cm}$ diameter and $13 \mathrm{~cm}$ height) at a rate of $6.4 \mathrm{BVh}^{-1}$. The biologically treated coke wastewater had initial concentrations of phenols and COD of 5.3 and $430 \mathrm{mg} \mathrm{L}^{-1}$, respectively. After the adsorption assays, regeneration was carried out in counter current mode at a linear velocity of $14.1 \mathrm{BV} \mathrm{h}^{-1}$ employing $6 \% \mathrm{NaOH}$ for the regeneration of $\mathrm{GAC}$ and $20 \% \mathrm{NaCl}$ and $2 \% \mathrm{NaOH}$ for the regeneration of the two resins.

\subsection{Chemical analyses}

The parameters analysed in the coke wastewater were: $\mathrm{pH}$, conductivity, chemical oxygen demand (COD), biochemical oxygen demand (BOD), suspended solids (SS), volatile

Table 4

Characteristics of the adsorbent resins employed

\begin{tabular}{lll}
\hline & AP-246 WS & VPOC-1074 \\
\hline Ionic form, as shipped & $\mathrm{Cl}^{-} / \mathrm{OH}^{-}$ & $\mathrm{Cl}^{-}$ \\
Grain shape & $\mathrm{Balls}$ & $\mathrm{Bead}_{-\mathrm{shaped}}$ \\
Appearance & Light-beige, opaque & White, opaque \\
Matrix & Polyacrylamide & $\mathrm{Cl}^{-} / \mathrm{OH}^{-}$ \\
Functional group & Quaternary amine & Polyacrylamide \\
Bead size & $0.3-1.25 \mathrm{~mm}$ & Quaternary amine \\
Effective size & $0.48 \mathrm{~mm}$ & $0.4-1.6 \mathrm{~mm}$ \\
Bulk density & $700-800 \mathrm{gL}^{-1}$ & $0.55 \mathrm{~mm}$ \\
Density & 1.08 & $680 \mathrm{gL}^{-1}$ \\
Water retention & $60-65 \%$ & 1.08 \\
Stability at pH range & $1-14$ & $65-72 \%$ \\
\hline
\end{tabular}




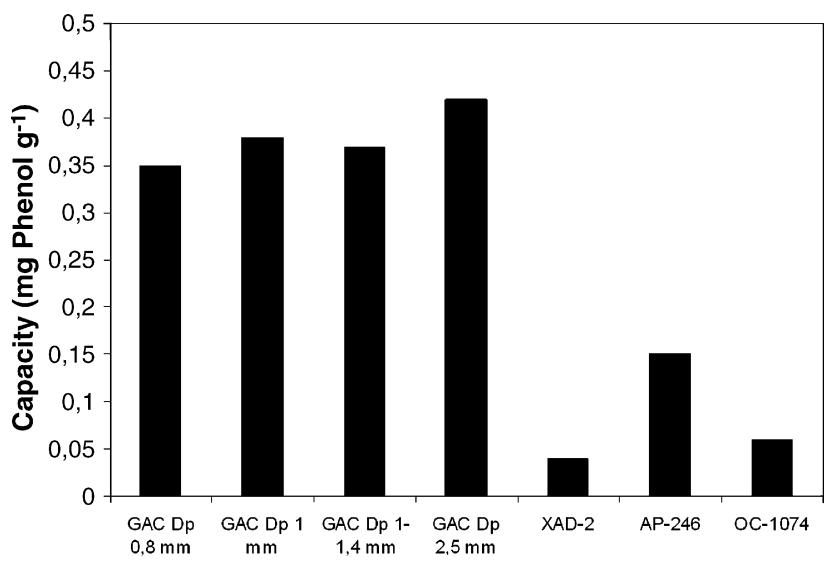

Fig. 2. Results of the batch preliminary adsorption assays.

suspended solids (VSS), phenols, oil and grease, alkalinity, Kjeldahl nitrogen, ammonium nitrogen, nitrate, thiocyanate, phosphate, cyanide, sulphate, sulphide, chloride and metals ( $\mathrm{Fe}, \mathrm{Mg}$ and $\mathrm{Ca}$ ).

Phenols and COD were determined for the adsorption study. All the analyses were performed according to Standard Methods [15].

\section{Results and discussion}

\subsection{Preliminary assays}

The results can be seen in Fig. 2. In general, GAC shows higher adsorption capacities than the resins. GAC capacities range from $0.35 \mathrm{mg} \mathrm{g}^{-1}$ for $0.8 \mathrm{~mm}$ diameter $\mathrm{GAC}$ to $0.45 \mathrm{mg} \mathrm{g}^{-1}$ for $2.5 \mathrm{~mm}$ diameter GAC. Among the resins, the best adsorption capacity was obtained with the AP-246 resin $\left(0.15 \mathrm{mg} \mathrm{g}^{-1}\right)$, followed by the OC-1074 resin and the XAD-2 resin.

\subsection{Equilibrium and kinetic assays}

In line with these results, equilibrium and kinetic assays were performed with GAC $2.5 \mathrm{~mm}$ diameter and the AP-246 and OC1074 resins. The equilibrium assays were fitted to Langmuir and Freundlich models. The Langmuir isotherm fits the following equation:

$q_{\mathrm{e}}=\frac{Q k C_{\mathrm{e}}}{1+k C_{\mathrm{e}}}$

where $q_{\mathrm{e}}$ is the amount sorbed per specified amount of sorbent ( $\left.\mathrm{mg} \mathrm{g}^{-1}\right), Q$ the sorption capacity to form the single layer $\left(\mathrm{mg} \mathrm{g}^{-1}\right), k$ the constant of the Langmuir equation related to the enthalpy of the process $\left(\mathrm{mg} \mathrm{L}^{-1}\right)^{-1}$, and $C_{\mathrm{e}}$ is the concentration of the species in solution $\left(\mathrm{mg} \mathrm{L}^{-1}\right)$.

This isotherm is applicable under the following hypothesis: (i) the solid has a uniform surface, (ii) absence of interactions between the solid molecules, and (iii) the sorption process takes place in a single layer.

The Freundlich isotherm fits the following equation:

$q_{\mathrm{e}}=K_{\mathrm{F}} C_{\mathrm{e}}^{1 / n}$

where $q_{\mathrm{e}}$ is the amount sorbed per specified amount of adsorbent $\left(\mathrm{mg} \mathrm{g}^{-1}\right), K_{\mathrm{F}}$ the constant related to the sorption capacity $\left(\mathrm{mg} \mathrm{L}^{-1}\right)^{-1}, C_{\mathrm{e}}$ the equilibrium concentration in solution $\left(\mathrm{mg} \mathrm{g}^{-1}\right)$, and $n$ is the empirical parameter related to the intensity of sorption, which varies with the heterogeneity of the material. When $1 / n$ values are in the range $0.1<1 / n<1$, the sorption process is favourable.

This model is valid for heterogeneous surfaces and predicts an increase in the concentration of the ionic species sorbed onto the surface of the solid with increasing concentrations of said species in the liquid phase.

The calculated Langmuir and Freundlich parameters are presented in Table 5. When applying the Langmuir model, the maximum phenol adsorption capacity in a single layer was obtained for GAC $\left(1.48 \mathrm{mg} \mathrm{g}^{-1}\right)$, the adsorption capacities of the resins being much lower $\left(0.07\right.$ and $0.04 \mathrm{mg} \mathrm{g}^{-1}$ for AP-246 and OC-1074, respectively). When fitted to the Freundlich equation, the value of $K_{\mathrm{F}}$ was higher for $\mathrm{GAC}, 0.97\left(\mathrm{mg} \mathrm{L}^{-1}\right)^{-1}$, and much lower for the resins. The $1 / n$ value was slightly unfavourable for GAC, with a value of 1.26 , whereas the values clearly indicate an unfavourable equilibrium for the resins.

The kinetic results were fitted to the Lagergren equation, based on solid capacity. The Lagergren equation is one of the most widely used sorption rate equations for the sorption of a solute from a liquid solution. It may be expressed as:

$$
\frac{\mathrm{d} q_{t}}{\mathrm{~d} t}=k^{\prime}\left(q_{\mathrm{e}}-q_{t}\right)
$$

Table 5

Langmuir and Freundlich parameters for phenol and COD adsorption onto GAC (2.5 mm) and resins AP-246 and OC-1074

\begin{tabular}{|c|c|c|c|c|c|c|}
\hline & \multicolumn{3}{|c|}{ Langmuir parameters } & \multicolumn{3}{|c|}{ Freundlich parameters } \\
\hline & $Q\left(\mathrm{mg} \mathrm{g}^{-1}\right)$ & $K\left(\mathrm{mg} \mathrm{L}^{-1}\right)^{-1}$ & $r$ & $K_{\mathrm{F}}\left(\mathrm{mg} \mathrm{g}^{-1}\right)$ & $1 / n$ & $r$ \\
\hline \multicolumn{7}{|l|}{ Phenol adsorption } \\
\hline Activated coal & 1.481 & 0.065 & 0.98 & 0.97 & 1.261 & 0.97 \\
\hline Resin AP-246 & 0.071 & 0.584 & 0.98 & 0.112 & 2.830 & 0.98 \\
\hline Resin OC-1074 & 0.043 & 0.445 & 0.99 & 0.0053 & 6.141 & 0.99 \\
\hline \multicolumn{7}{|l|}{ COD adsorption } \\
\hline Activated coal & 74.626 & 0.0023 & 0.99 & $1.483 \times 10^{-6}$ & 3.258 & 0.99 \\
\hline Resin AP-246 & 0.423 & 0.0036 & 0.99 & $2.15 \times 10^{-36}$ & 15.102 & 0.98 \\
\hline Resin OC-1074 & 3.559 & 0.0021 & 0.96 & $2.90 \times 10^{-8}$ & 3.352 & 0.96 \\
\hline
\end{tabular}




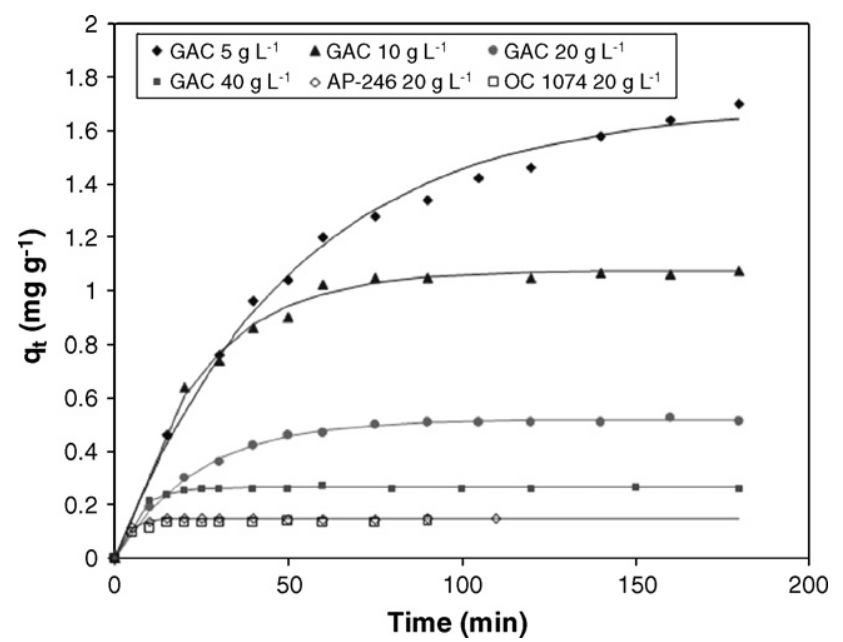

Fig. 3. Kinetics of phenol adsorption on GAC fitted to Lagergren equation.

Integrating this equation between $t=0$ and $t$ and $q_{t}=0$ and $q_{t}$, we obtain:

$\log \left(\frac{q_{\mathrm{e}}}{q_{\mathrm{e}}-q_{t}}\right)=\frac{k^{\prime}}{2.303} t$

This is the integrated rate law for a pseudo-first order reaction, where $q_{\mathrm{e}}$ is the amount of substrate sorbed at equilibrium $\left(\mathrm{mg} \mathrm{g}^{-1}\right), q_{\mathrm{t}}$ the amount sorbed at time $t\left(\mathrm{mg} \mathrm{g}^{-1}\right)$ and $k^{\prime}$ is the equilibrium rate constant $\left(\mathrm{min}^{-1}\right)$ [16].

The experimental data fitted to the Lagergren equation are shown in Fig. 3 and Table 6. In all cases, the regression coefficient was higher than 0.996 . The $q_{\mathrm{e}}$ values obtained for an initial adsorbent concentration of $20 \mathrm{~g} \mathrm{~L}^{-1}$ were $0.52,0.15$ and $0.14 \mathrm{mg} \mathrm{g}^{-1}$ for GAC, resin AP-246 and resin OC-1074, respectively. Experiments with different adsorbent dosages, performed using GAC, clearly show that when the dosage is increased, the adsorption capacity decreases, as expected. The capacity decreased from $1.69 \mathrm{mg} \mathrm{g}^{-1}$ for $5 \mathrm{~g} \mathrm{GACL}^{-1}$ to $0.26 \mathrm{mg} \mathrm{g}^{-1}$ for $40 \mathrm{~g} \mathrm{GAC} \mathrm{L}^{-1}$.

With respect to the influence of phenol concentration, the results obtained, shown in Fig. 4, indicate that when the phenol concentration increases, the adsorption capacity also increases for the same dosage of activated carbon $\left(40 \mathrm{gL}^{-1}\right)$. The $q_{\mathrm{e}}$

Table 6

Lagergren parameters for phenol adsorption onto GAC $(2.5 \mathrm{~mm})$ and resins AP-246 and OC-1074

\begin{tabular}{llll}
\hline & \multicolumn{2}{l}{ Kinetic equation } & \\
\cline { 2 - 4 } & $q_{\mathrm{e}}$ & $k^{\prime}$ & $r$ \\
\hline $\begin{array}{l}\text { Activated coal } \\
5 \mathrm{~g} \mathrm{~L}^{-1}\end{array}$ & 1.693 & 0.0195 & 0.9968 \\
$10 \mathrm{~g} \mathrm{~L}^{-1}$ & 1.076 & 0.0419 & 0.9974 \\
$20 \mathrm{~g} \mathrm{~L}^{-1}$ & 0.519 & 0.0430 & 0.9990 \\
$40 \mathrm{~g} \mathrm{~L}^{-1}$ & 0.264 & 0.1624 & 0.9985 \\
Resin AP-246 & & & 0.9975 \\
$20 \mathrm{~g} \mathrm{~L}^{-1}$ & 0.149 & 0.2897 & \\
Resin OC-1074 & & & 0.9963 \\
$20 \mathrm{~g} \mathrm{~L}^{-1}$ & 0.137 & 0.2246 & \\
\hline
\end{tabular}

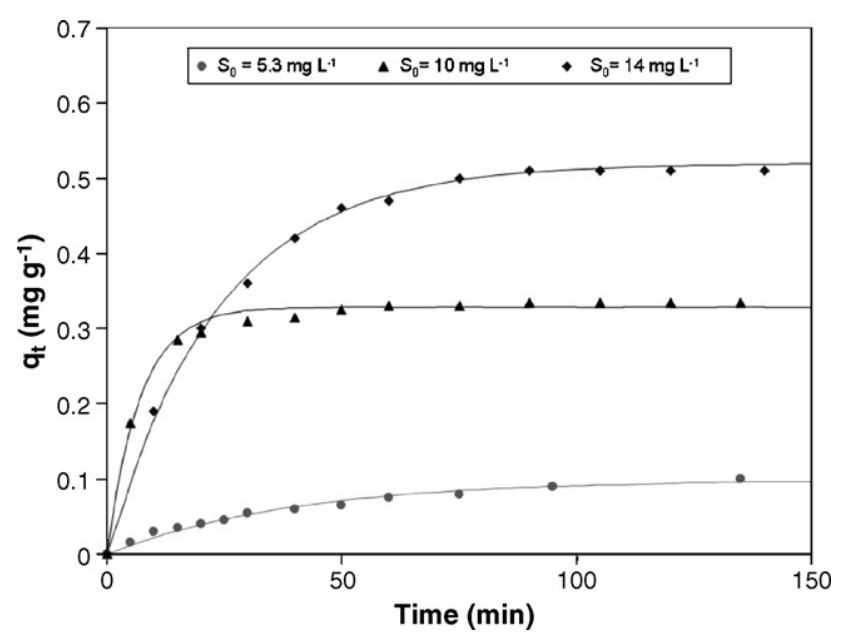

Fig. 4. Influence of phenol concentration on the adsorption capacity of GAC.

increased from 0.1 to $0.5 \mathrm{mg} \mathrm{g}^{-1}$ when the phenol concentration changed from 5.3 to $14 \mathrm{mg} \mathrm{L}^{-1}$.

\subsection{Column assays}

Figs. 5-7 show the breakthrough curves obtained in the column assays using the different adsorbents. In keeping with the results obtained in the equilibrium and kinetic assays, GAC showed the best capacity for phenol adsorption. It was possible to treat $450 \mathrm{BV}$, obtaining an effluent concentration $\leq 1.6 \mathrm{mg} \mathrm{L}^{-1}\left(C / C_{0}=0.30\right)$; for $480 \mathrm{BV}$, the adsorption capacity was $1.82 \mathrm{mg} \mathrm{mL}^{-1}$ (asymptotic curve).

The AP-246 and OC-1074 resins presented poorer adsorption characteristics; when treating 200-250 BV, the phenol concentration in the effluent was $1.9-2.1 \mathrm{mg} \mathrm{L}^{-1}\left(C / C_{0}=0.35-0.4\right)$. Saturation capacities were similar for both resins, around $1.1 \mathrm{mg} \mathrm{mL}^{-1}$.

The adsorption of COD was much lower than the adsorption of phenol, the effluent reaching a concentration of $344 \mathrm{mg} \mathrm{L}^{-1}$ $\left(C / C_{0}=0.8\right)$ with $100 \mathrm{BV}$ for $\mathrm{GAC}$ and with $50 \mathrm{BV}$ for the resins.

The results of the regeneration of the three adsorbents are shown in Fig. 8. Around 20 BV were needed to regenerate the

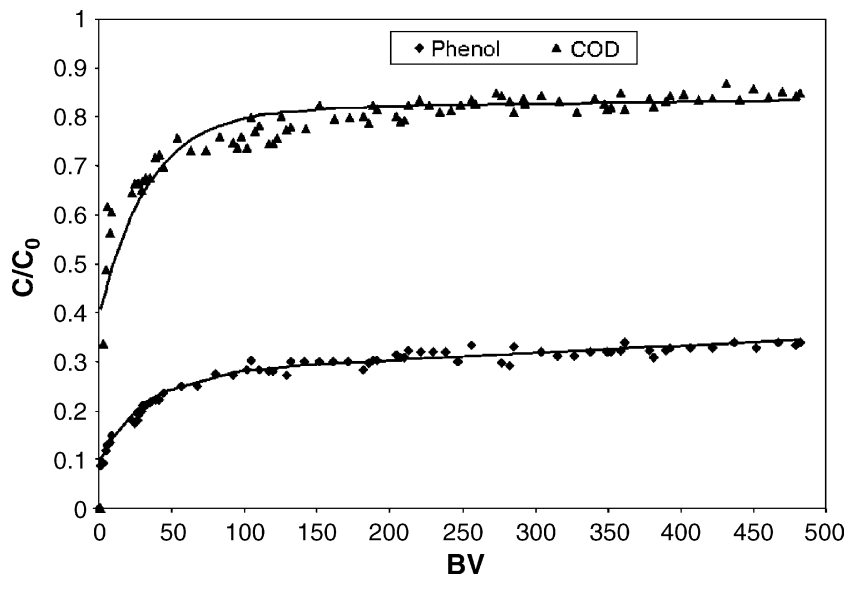

Fig. 5. Breakthrough curves obtained with GAC. 


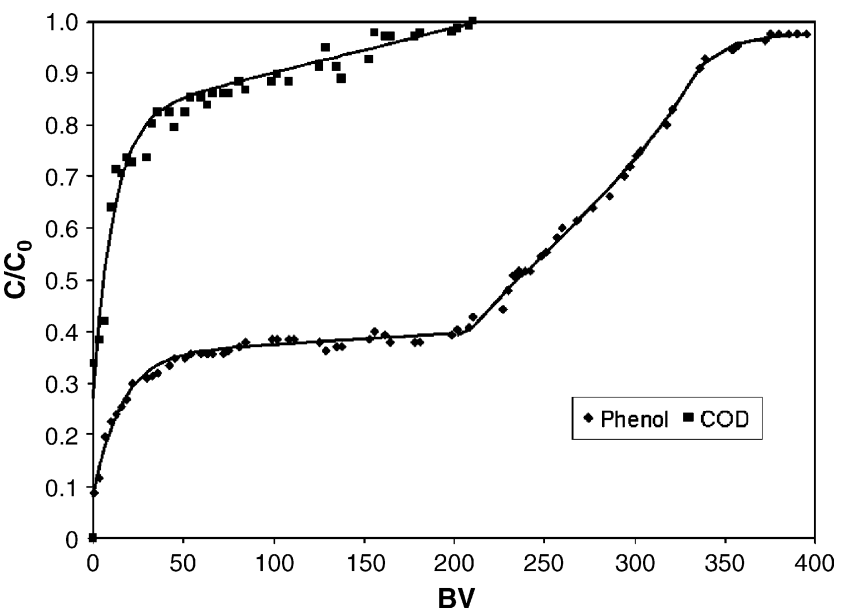

Fig. 6. Breakthrough curves obtained with resin AP-246.

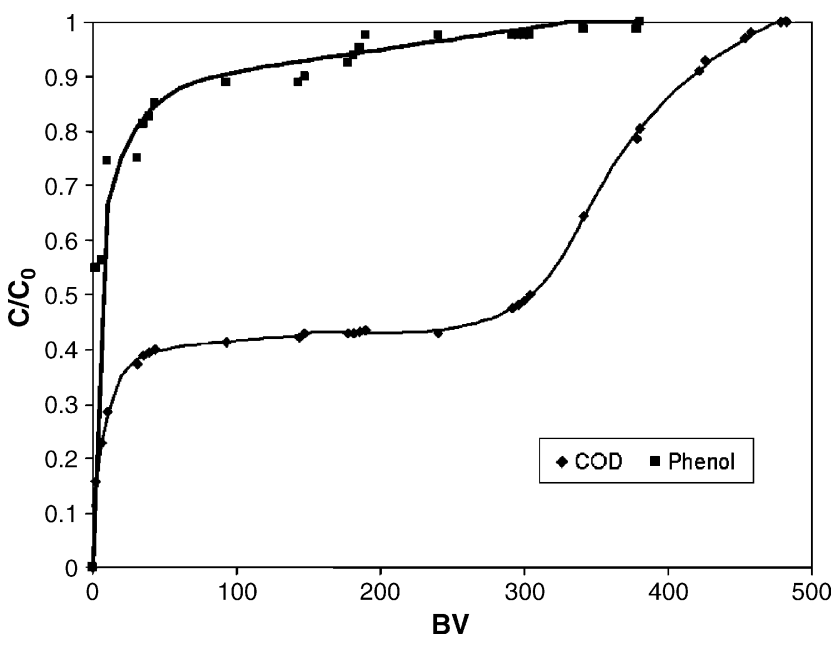

Fig. 7. Breakthrough curves obtained with resin OC-1074.

resins, although the regeneration capacity was not very good: $64.5 \%$ for OC-1074 and $38.1 \%$ for AP-246. It was not possible to regenerate the $\mathrm{GAC}$ with $6 \% \mathrm{NaOH}$ (the regeneration capacity was only $3 \%$ ). However, due to the lower price of this adsorbent and to the loss in properties when regeneration is carried out (reduction of the pore surface), the current ten-

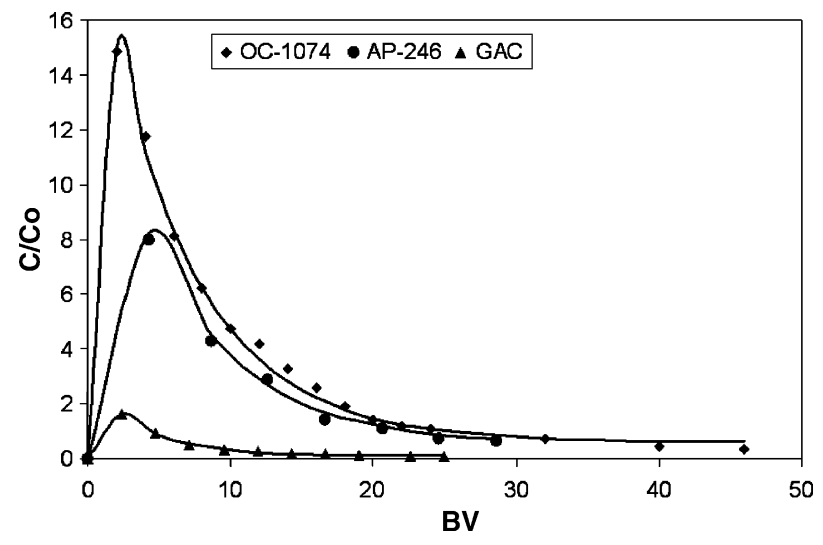

Fig. 8. Regeneration curves for the adsorbents GAC, AP-246 and OC-1074. dency is the disposal or incineration of this adsorbent after its exhaustion.

\section{Conclusion}

Residual phenols from high load industrial wastewater biological treatment plants can be efficiently removed using activated carbon. The concentration of pollutants after adsorption permits the effluent to be discharged into the sewage system for subsequent treatment at a sewage plant. The other adsorbents tested in this study (XAD-2, AP-246 and OC-1074 resins) were less adequate, especially XAD-2, due to their lower adsorption capacities.

\section{Acknowledgements}

The authors gratefully acknowledge the funding received from the European Union for the project "Advanced Process Control for Biological Water Treatment Plants in Steelworks", Contract no. ECSC-7210-PR-235, and the Arcelor Group for their collaboration. They also wish to thank Mr. Paul Barnes for proof reading the English version of the manuscript.

\section{References}

[1] J. Wanmmer, The implementation of bulking control in design of activated sludge systems, Water Sci. Technol. 29 (7) (1994) 193-202.

[2] G.M. Wong-Chong, Retrofitting LTV coke plant wastewater treatment system to comply with pretreatment discharge limits, Iron Steel Eng. (1994) 26-28.

[3] D. Bamelis, Biological purification of coking plant waters, Rev. Metall. (1992) 132-145.

[4] D. Jenkins, Towards a comprehensive model of activated sludge bulking and foaming, Water Sci. Technol. 25 (6) (1992) 215-230.

[5] W. Keith, J. Antil, Biotreatment of coke oven effluent, Steel Time Int. (1991) 26-35.

[6] I. Vázquez, Estudio y modelización de la eliminación biológica de contaminantes en aguas de coquería, Doctoral Thesis, University of Oviedo, 2005.

[7] S. Schacht, J. Klein, Biological removal of pollutants. New process for the treatment of coking plant wastewater, Energie 41 (10) (1989) 32-37.

[8] G. González, G. Herrera, Ma.T. García, M. Peña, Biodegradation of phenolic industrial wastewater in a fluidized bed reactor with immobilized cells of Pseudomonas putida, Bioresour. Technol. 80 (2001) 137-142.

[9] G. González, G. Herrera, Ma.T. García, M. Peña, Biodegradation of phenol in a continuous process: comparative study of stirred tank and fluidised-bed bioreactors, Bioresour. Technol. 76 (2001) 245-251.

[10] S.T. Christoskova, M. Stoyanova, Degradation of phenolic wastewaters over Ni-oxide, Water Res. 35 (8) (2001) 2073-2077.

[11] C.S.A. Sá, R.A.R. Boaventura, Biodegradation of phenol by Pseudomonas putida DSM 548 in a trickling bed reactor, Biochem. Eng. J. 9 (2001) 211-219.

[12] C. Aharoni, C.L. Sparks, Kinetics of soil chemical processes: a theoretical treatment, in: D.L. Sparks, D.L. Suárez (Eds.), Rates of Soil Chemical Processes. Soil Sci. Soc. Am. Madison, 1991, pp. 1-18.

[13] Q. Wu, X. Hu, P.L. Yue, Kinetics study on catalytic wet air oxidation of phenols, Chem. Eng. Sci. 58 (2003) 923-928.

[14] C.B. Maugans, A. Akgerman, Catalytic wet oxidation of phenol in a trickle bed reactor over a Pt/TiO 2 catalyst, Water Res. 37 (2003) 319-328.

[15] APHA, AWWA, WEF, Standard Methods for the Examination of Water and Wastewater, 20th ed., APHA/AWWA/WEF, Washington, DC, 1998.

[16] I. Alemzadeh, F. Vossoughi, M. Houshmande, Phenol biodegradation by rotating biological contactor, Biochem. Eng. J. 11 (2002) 19-23. 